Southern Illinois University Carbondale

OpenSIUC

Articles

Department of Mechanical Engineering and

Energy Processes

$11-2011$

\title{
An Environmental Analysis of Illinois Coal Entry into the Transportation Market
}

\author{
Darin M. Starkey \\ Southern Illinois University Carbondale \\ James A. Mathias \\ Southern Illinois University Carbondale \\ Bradley C. Paul \\ Southern Illinois University Carbondale
}

Follow this and additional works at: https://opensiuc.lib.siu.edu/meep_articles

This is an Author's Accepted Manuscript of an article published in Energy Sources, Part A:

Recovery, Utilization, and Environmental Effects , Vol. 34, No. 1 (2011) (copyright Taylor \&

Francis), available online at the link below.

\section{Recommended Citation}

Starkey, Darin M., Mathias, James A. and Paul, Bradley C. "An Environmental Analysis of Illinois Coal Entry into the Transportation Market." Energy Sources, Part A: Recovery, Utilization, and Environmental Effects 34, No. 1 (Nov 2011): 72-81. doi:10.1080/15567030903530574.

This Article is brought to you for free and open access by the Department of Mechanical Engineering and Energy Processes at OpenSIUC. It has been accepted for inclusion in Articles by an authorized administrator of OpenSIUC. For more information, please contact opensiuc@lib.siu.edu. 


\title{
ENVIRONMENTAL ANALYSIS OF ILLINOIS COAL ENTRY INTO THE TRANSPORTATION MARKET
}

\section{Shortened Title: ENVIRONMENTAL ANALYSIS OF USING COAL IN TRANSPORTATION}

\author{
Darin M. Starkey, James A. Mathias* \\ Department of Mechanical Engineering and Energy Processes \\ Bradley C. Paul \\ Department of Mining and Mineral Resources Engineering \\ Southern Illinois University Carbondale
}

* Corresponding author: 1230 Lincoln Drive, Mailcode 6603, Carbondale, IL 62901, 618-453-7016,618-453-7658 (fax), mathias@engr.siu.edu

\begin{abstract}
Using Illinois coal in transportation has varied environmental consequences. This study calculated the total $\mathrm{CO}_{2}$ emissions from gasoline and eight other vehicle propulsion methods (VPMs) involving Illinois coal. VPMs of Ultra Super Critical electrical cycle (USC), Integrated Gasification Combined electrical Cycle (IGCC), Pulverized coal in a Sub-Critical electrical cycle (PSC), and electricity from a hydrogen fuel cell emitted the lowest $\mathrm{CO}_{2}$. VPMs using Illinois coal to produce ethanol, butanol, and IGCC/ethanol emitted $\mathrm{CO}_{2}$ comparable to gasoline. The VPM of Fischer-Tropsch (FT) diesel emitted the most $\mathrm{CO}_{2}$. It was concluded that energy efficiency and $\mathrm{CO}_{2}$ offset from agricultural growth and by-products were the most influential factors of $\mathrm{CO}_{2}$ emissions.
\end{abstract}




\section{Introduction}

The abundance of coal, high oil prices, and a possible carbon tax are factors that have created an opportunity for Illinois coal to enter the transportation market and become economically competitive with petroleum fuels. Illinois' coal reserves contain more energy than the oil reserves of Saudi Arabia and Kuwait combined (Lavin 2006). Using these coal reserves for vehicle propulsion could decrease dependency on expensive oil and benefit the economy.

Environmental effects, specifically $\mathrm{CO}_{2}$ emissions, need to be determined when using alternative fuels to propel vehicles. Burning fossil fuels rapidly releases carbon that has been in the earth for millions of years. Experts argue that continued increase in $\mathrm{CO}_{2}$ in the earth's atmosphere will have dire consequences. For this reason a possibility arises for the government to institute a carbon tax. A uniformly applied tax, most likely based on net $\mathrm{CO}_{2}$ emission, would make vehicle propulsion methods (VPMs) that use coal and have low carbon emissions economically favorable compared to petroleum fuels, however, many proposals are very selectively applied. In this study, life cycle $\mathrm{CO}_{2}$ emissions for a passenger vehicle traveling 100,000 miles were determined for gasoline and eight vehicle propulsion methods (VPMs) involving Illinois coal.

Other studies have calculated the energy use and green house gas emissions of VPMs or specific sections in VPMs. Two studies, (Wang et al. 2001) and (Delucchi 2003), used spread sheet based programs with built in assumptions to make their calculations. These assumptions were modified according to specific fuel and automobile conditions of various VPMs. Two other studies, (Shapouri et al. 2002) and (Spath et al. 1999), made calculations of emissions of ethanol and electricity production, respectively. The scope of their studies started with feedstock acquisition and ended after production. Finally, two more studies, (Chiesa et al. 2005) and 
(Challman 2007), performed calculations of gasifying coal to make hydrogen and diesel fuel, respectively and the scope of their studies was only fuel production. This study is unique from others who focus on green house gas emissions from VPMs because it analyzes VPMs that use a significant amount of coal.

For this study, a gasoline powered vehicle was used as the base case. This method assumed gasoline was made from oil and burned in a traditional engine. The next methods evaluated electricity generated for use in electric vehicles. These methods include: electricity from Pulverized coal in a Sub-Critical power cycle (PSC), electricity from Integrated Gasification Combined power Cycle (IGCC), and electricity from an Ultra Super Critical power cycle (USC). Another category of methods evaluated made fuels from the gasification of coal. These methods consisted of hydrogen and Fischer-Tropsch (FT) diesel. This study assumed hydrogen was used to produce electricity in a fuel cell vehicle and diesel was used in a conventional diesel engine. Additional methods assumed that bio fuels, either ethanol or butanol, were made from corn using coal for process heat and this bio fuel was burned in a traditional engine similar to gasoline. The last method considered combined IGCC and ethanol. Waste heat from the IGCC power plant was assumed to be the process heat in ethanol production, hence producing both electricity and ethanol. Electric and ethanol vehicles were assumed to be driven in the same ratio of the fuels produced. Vehicles used for all methods were assumed to be mid-sized passenger automobiles.

This study assumed Illinois \# 6 coal was used for all coal inputs in each VPM. Coal was assumed to be used for all major thermal inputs in every VPM but gasoline. Also, all electricity inputs were considered to be made $100 \%$ from coal for all methods. The heating value of Illinois coal ranges from 10,000 to 14,000 BTU/lb coal (Lavin 2006) and the value used for this research 
falls close to the middle of this range at 11,666 BTU/lb coal (Klara 2007). The $\mathrm{CO}_{2}$ emission factor used in this study was $2.374 \mathrm{lb} \mathrm{CO} / \mathrm{lb}$ coal burned (Hong and Slatick 1994). This value was assumed for all coal used in all VPMs. In addition, it was assumed that carbon completely reacted, in combustion, fermentation, or gasification, producing a $\mathrm{CO}_{2}$ molecule for every carbon atom in the reaction.

\section{Procedure}

The accounting of the total $\mathrm{CO}_{2}$ emissions from all the VPMs required investigation into the life cycle of each. It was determined that all VPMs consist of four general life cycle steps; (1) feedstock acquisition, (2) material transportation, (3) fuel production, and (4) fuel use. Standard methods for all steps were designated for each VPM and the $\mathrm{CO}_{2}$ emission was calculated in each step specific to one common fuel unit.

The $\mathrm{CO}_{2}$ emission values were either directly taken or derived from existing literature. Most $\mathrm{CO}_{2}$ values were calculated by using documented energy requirement and fuel composition data (Table 1) along with each of the fuels heating value and $\mathrm{CO}_{2}$ emission ratio (Table2. Other $\mathrm{CO}_{2}$ emission values were directly obtained from literature, shown in Table 3. Also considered was $\mathrm{CO}_{2}$ offset emissions, which is contributed to removing $\mathrm{CO}_{2}$ from the atmosphere during corn growth or reducing $\mathrm{CO}_{2}$ emission by replacing a product, with a co-product. Co-product production and replacement values as well as photosynthesis ratios are in Table 3.

The summation of all $\mathrm{CO}_{2}$ values from every step was divided by the fuel efficiency (Table 3) for that specific fuel to yield pounds of $\mathrm{CO}_{2}$ per mile and lastly all VPMs were compared for 100,000 miles of travel.

The gasoline VPM was the base case method evaluated for $\mathrm{CO}_{2}$ emission. The major steps in gasoline’s life cycle include: oil extraction, oil refining, gasoline transportation, and 
vehicle use. The specific data used to calculate oil extraction, oil/gasoline transportation, oil refining, and vehicle are shown in Table 3. All $\mathrm{CO}_{2}$ emission values were found based on one gallon of end use gasoline ready at a gas station.

The electricity VPMs assumed that Illinois coal was used to generate electricity that was transmitted to a power outlet over the grid and used to charge an electric vehicle. The electricity methods evaluated consist of PSC electricity, IGCC electricity, and USC electricity. The major steps considered for these methods were coal extraction, coal transportation, electricity generation, and vehicle use. The specific data of coal extraction, coal transportation, electricity generation, and vehicle use are shown in Table 3. All $\mathrm{CO}_{2}$ emission values were found based on one kWh of end use electricity ready at the plug.

The gasification fuel synthesis VPMs gasified Illinois coal into synthetic gas to make fuels to propel a vehicle. These methods include Fischer-Tropsch (FT) diesel used in a diesel engine and hydrogen used in a fuel cell vehicle. The major steps in these VPMs consisted of coal extraction, coal transportation, fuel transportation, coal gasification/fuel synthesis, and vehicle use. All $\mathrm{CO}_{2}$ emission values were found based on one gallon of end use diesel or one pound of end use hydrogen ready at their respective fueling stations. The specific data for the hydrogen and diesel production facilities as well as their respective vehicle fuel efficiencies are shown in Table 3. A $\mathrm{CO}_{2}$ offset was attributed to the co production of electricity at both of the gasification facilities.

Coal supplied the energy needs of corn-to-fuel conversion for the VPMs using biofuels, which was then burned in a biofuel capable vehicle. These methods consisted of producing ethanol, butanol, and a combination ethanol/IGCC. The major steps considered for $\mathrm{CO}_{2}$ emission in the biofuel methods were corn farming, corn and ethanol transportation, biofuel 
production, and vehicle use. Also considered, however less significant, were coal mining and transportation steps. All $\mathrm{CO}_{2}$ emission values were found based on one gallon of end use biofuel ready at the fueling stations. The specific data for corn farming, material transportation, biofuel production, and vehicle fuel efficiencies are shown in Table $3 . \mathrm{CO}_{2}$ offset was attributed to the co production of Dried Distiller Grain with Solubles (DDGS), Corn Gluten Meal (CGM), Corn Gluten Feed (CGF), and corn oil at the biofuel facilities as well as from photosynthesis during corn growth.

In all VPMs, $\mathrm{CO}_{2}$ emission was accounted for from the construction of fuel production facilities, manufacturing material for feedstock acquisition equipment, assembling the equipment, and repairing the equipment. These minor emissions were calculated using the same method as discussed previously. Detailed explanations of all calculations made for all emissions can be found in literature (Starkey 2009).

\section{RESULTS}

The $\mathrm{CO}_{2}$ emission from all VPMs was determined and shown graphically in this section. Figure 1 shows specific emissions from feedstock acquisition, material transfer, fuel production, and vehicle use stacked together in one multi-patterned, stacked column that represents the gross $\mathrm{CO}_{2}$ emission per 100,000 miles for each VPM. Also, Figure 1 shows the net $\mathrm{CO}_{2}$ emission per 100,000 miles for each VPM represented by the hollow dotted line column. Lastly, the $\mathrm{CO}_{2}$ offset is graphically represented by the vertical distance between the top of the two stacked and dashed columns.

\section{DISCUSSION AND CONCLUSIONS}

The results show the VPMs using electricity emit less $\mathrm{CO}_{2}$ than other VPMs and provide about 30\% reduction in $\mathrm{CO}_{2}$ emissions relative to gasoline. Also, these substantial reductions in 
$\mathrm{CO}_{2}$ emission correspond to the near commercial release of electric cars, which is an area of promise. Less $\mathrm{CO}_{2}$ was emitted from electricity VPMs mainly due to the higher efficiency of electricity generation compared to power generated by a gasoline or diesel engine.

Unfortunately the pitfalls of selectively applied carbon tax legislation or cap and trade systems may work against net $\mathrm{CO}_{2}$ reductions by discouraging the shift to electric vehicles. Much of the most favored carbon tax legislation targets electric generation, with milder applications to industrial sources, and no application at all to the carbon emissions directly from vehicles. Observing Figure 1 it is noted that about $82 \%$ of the $\mathrm{CO}_{2}$ emission from gasoline powered vehicles is released at the tailpipe where proposed carbon legislation would apply no financial penalty. The remaining $18 \%$ is from industrial sources that would face some costs, but not the extent faced by electric power producers that would be charged for all carbon emissions. By contrast if one refers again to Figure 1 it is noted that about $98 \%$ of emissions from electric vehicles are in fully taxed power generation and none of the emissions are in the tax exempt tailpipe category.

This may work against reductions in total U.S. carbon emissions since passenger transportation and electric power generation account for roughly equal one-third parts of the total. While, not a part of this study, there is good consensus in a wide variety of sources that gasoline prices will soon rise to the range where electric vehicles, with their 30\% drop in carbon emissions, would be economically preferred to gasoline without government intervention. Proposed carbon tax legislation, intended to double electric power costs into the range where renewable energy sources can compete, will create a market distortion against this shift, since electric car owners would pay full carbon tax on both their fuel and the additional energy needed to produce batteries, versus simple plastic gas tanks on conventional vehicles. 
Very different results were found for the VPMs of Gasification and Fuel Synthesis. Hydrogen VPM had the next greatest $\mathrm{CO}_{2}$ savings of about $18 \%$ versus gasoline. The reductions were due to high efficiency of the electric, fuel cell vehicle after the hydrogen had been produced. Unfortunately, unlike electric cars, the release date for hydrogen fuel cell vehicles and the refueling network that will be needed has not been set by manufacturers.

FT Diesel VPM produced more $\mathrm{CO}_{2}$ during fuel production than Hydrogen VPM due to an overall less efficient production process and then utilized the fuel in a typical diesel engine, which is more efficient than gasoline but much less efficient than electricity. Because of this the FT Diesel VPM had the highest $\mathrm{CO}_{2}$ emission of any VPM. $\mathrm{CO}_{2}$ sequestration was not evaluated during this study, but sequestration would be easier for Gasification and Fuel Synthesis VPMs because the $\mathrm{CO}_{2}$ is more concentrated during the process and hence easier to remove compared to capturing $\mathrm{CO}_{2}$ after a combustion process.

The VPMs using bio fuels emitted less $\mathrm{CO}_{2}$ than gasoline largely due to the $\mathrm{CO}_{2}$ offset from plant growth and production of co products. The results of this study assume all co products are completely utilized. However, if co products are not fully utilized this decreases the $\mathrm{CO}_{2}$ saved, hence increasing the $\mathrm{CO}_{2}$ emitted. Without full utilization of all co products, biofuels likely increases $\mathrm{CO}_{2}$ emitted relative to the baseline gasoline case.

The overall energy efficiency was the biggest factor in determining the $\mathrm{CO}_{2}$ emitted. The four lowest $\mathrm{CO}_{2}$ emitting VPMs have the highest overall efficiency in the same order. The other 5 VPMs on average propelled a vehicle 55\% less miles per energy than the four most efficient VPMs. Overall energy efficiency, net $\mathrm{CO}_{2}$ emitted, and $\mathrm{CO}_{2}$ offset are shown for all VPMs in Figure 2. 
Since overall efficiency is the greatest determining factor for $\mathrm{CO}_{2}$ emission a sensitivity analysis was performed. Increasing the power plant efficiency in the PSC electricity VPM from 36.8 to $37.8 \%$ reduces $\mathrm{CO}_{2}$ emissions by 2000 pounds per 100,000 miles. Also concerning the electricity VPMs, reducing electricity transmission losses from 8 to $4 \%$ removes 3000 pounds of $\mathrm{CO}_{2}$ for the PSC electricity VPM. Increasing the efficiency of the gasification plant from 49.6 to $50.6 \%$ reduces $\mathrm{CO}_{2}$ emissions by 4000 pounds; similar reduction in $\mathrm{CO}_{2}$ emission was found for the hydrogen VPM. Concerning bio fuels, reducing the energy demand of the ethanol production facility by $1 \%$, which is different than increasing the plant efficiency by $1 \%$, reduces $\mathrm{CO}_{2}$ emitted by 730 pounds.

With these factors in mind it would seem that Illinois coal can be used in the passenger automobile transportation process reducing dependence on oil imports and what may become increasingly tight supplies of oil in general. This shift to coal can be made while achieving major reductions $\mathrm{CO}_{2}$ emissions. The best way to achieve these reductions is through electric, or hydrogen fuel cell, vehicles and natural market forces in supply and demand will likely favor this shift to commercial ready technology without the need for government intervention. In fact, government intervention if it took the form of selectively applied carbon charges or taxes, could work against the shift and the net emissions reductions it would bring. 
Table 1. Energy Requirement and Fuel Composition of the Fuels Used to Provide that Energy at different steps in each VPM

\begin{tabular}{|c|c|c|c|c|c|c|c|c|c|}
\hline \multirow{2}{*}{$\begin{array}{c}\text { VPM Classification } \\
\text { VPM }\end{array}$} & \multirow{2}{*}{$\begin{array}{l}\text { Baseline } \\
\text { Gasoline } \\
\text { (BTU/gal) }\end{array}$} & \multicolumn{3}{|c|}{ Electricity (BTU/kWh) } & \multicolumn{2}{|c|}{$\begin{array}{l}\text { Gasification/Fuel } \\
\text { Synthesis }\end{array}$} & \multicolumn{3}{|c|}{ Biofuels (BTU/gal) } \\
\hline & & PSC & IGCC & USC & $\begin{array}{c}\mathrm{H}_{2} \\
\text { (BTU/lb) }\end{array}$ & $\begin{array}{l}\text { FT Diesel } \\
\text { (BTU/gal) }\end{array}$ & Ethanol & Butanol & Ethanol/IGCC \\
\hline $\begin{array}{c}\text { Minor Energy } \\
\text { Requirements* }\end{array}$ & 267 & 10 & 10 & 9 & 369 & 311 & 3,112 & 4,193 & 3,295 \\
\hline $\begin{array}{l}\text { Feedstock Acquisition } \\
\text { Energy Requirements }\end{array}$ & $\begin{array}{c}7,588 \text { [1] } \\
65 \% \text { coal } \\
25 \% \text { NG } \\
6 \% \text { diesel } \\
4 \% \text { petroleum }\end{array}$ & $\begin{array}{c}122[2] \\
100 \% \\
\text { coal }\end{array}$ & $\begin{array}{l}118[2] \\
100 \% \\
\text { coal }\end{array}$ & $\begin{array}{c}112[2] \\
100 \% \\
\text { coal }\end{array}$ & $\begin{array}{l}1,292[2,3] \\
100 \% \text { coal }\end{array} \mid$ & $\begin{array}{l}3,854[2,4] \\
100 \% \text { coal }\end{array}$ & $\begin{array}{c}21,606[5,6] \\
38 \% \text { NG } \\
23 \% \text { Coal } \\
23 \% \text { diesel } \\
9 \% \text { LPG } \\
7 \% \text { gasoline }\end{array}$ & $\begin{array}{c}28,060[5,6] \\
\text { 38\% NG } \\
\text { 23\% Coal } \\
\text { 23\% diesel } \\
\text { 9\%LPG } \\
7 \% \text { gasoline }\end{array}$ & $\begin{array}{c}23,779 \\
{[2,5,6]} \\
\\
35 \% \text { NG } \\
30 \% \text { Coal } \\
21 \% \text { diesel } \\
8 \% \text { LPG } \\
6 \% \text { gasoline }\end{array}$ \\
\hline $\begin{array}{l}\text { Material Transportation } \\
\text { Energy Requirements } \\
\text { Provided by } 100 \% \text { diesel }\end{array}$ & $865[7-9]$ & $\begin{array}{c}57 \\
{[7,10,11]}\end{array}$ & $\begin{array}{c}55 \\
{[7,10,11]}\end{array}$ & $\begin{array}{c}53 \\
{[7,10,11]}\end{array}$ & $\left|\begin{array}{c}14,786 \\
{[7,9,10,11]}\end{array}\right|$ & $\begin{array}{c}3,519 \\
{[5,7,10,11]}\end{array}$ & $\begin{array}{c}3,851 \\
{[5,7,10,11]}\end{array}$ & $\begin{array}{c}4,564 \\
{[5,7,10,11]}\end{array}$ & $\begin{array}{c}5,586 \\
{[5,7,10,11]}\end{array}$ \\
\hline $\begin{array}{l}\text { Fuel Production Energy } \\
\text { Requirements** }\end{array}$ & $15,963[12]$ & $9,276[13]$ & $\begin{array}{c}8,922 \\
{[13]}\end{array}$ & $8,684[14]$ & $98,128[3]$ & 292,585 [4] & $56,236[15]$ & $95,430[16]$ & $\begin{array}{c}164,946 \\
{[13,15]}\end{array}$ \\
\hline
\end{tabular}

[1] (Evans 2004); [2] (Spath et al. 1999); [3] (Chiesa et al. 2005); [4] (Challman 2007); [5] (Shapouri et al. 2002); [6] (Shapouri et al. 1995); [7] (REI 2006); [8] (Business Wire 2001); [9] (Ogden 2004); [10] (Illinois Coal Industry 2007); [11] (AAR 2005); [12] (Wang et al. 2004); [13] (Klara 2007);

[14] (Goidich et al. 2005); [15] (Graboski 2002); [16] (Wu et al. 2007)

* Minor energy requirements consist of five sources: (1) energy to make raw materials for feedstock equipment, (2) energy to assemble feedstock acquisition equipment, (3) energy to repair feedstock acquisition equipment, (4) energy to build fuel production facilities, (5) energy to prepare coal used indirectly. The composition of the fuel used to provide this energy is about 80\% coal and 20\% Diesel. (Shapouri , Duffield, and Wang 2002); (Spath, Mann, and Kerr 1999); (Chiesa et al. 2005); (Challman 2007); (Klara 2007); (Evans 2004); (Graboski 2002); (Daly 2008); (Susta, Seon, and Melaysia 2004); (USDL 2007); (Wu, Wang, and Huo 2006);

** Fuel production energy requirements are all provided by $100 \%$ by coal except for gasoline which is $81 \%$ oil and $19 \%$ coal 
Table 2: The Higher Heating Value and Carbon Dioxide Ratio of Fuels

\begin{tabular}{|c|c|c|}
\hline Fuel & $\begin{array}{c}\text { Higher Heating Value } \\
\text { (BTU/fuel unit) }\end{array}$ & $\begin{array}{c}\text { Carbon Dioxide Emission Ratio } \\
\text { (lb CO } \text { CO}_{\text {fuel unit) }}\end{array}$ \\
\hline Illinois coal & 11,666 (BTU/lb) [1] & 2.37 (lb/lb) [6] \\
\hline Gasoline & 125,070 (BTU/gallon) [2] & 19.4 (lb/gallon) [2] \\
\hline Heavy diesel & 138,095 (BTU/gallon) [2] & 26 (lb/gallon) [2] \\
\hline Light diesel & 137,550 (BTU/gallon) [2] & 22.2 (lb/gallon) [2] \\
\hline Natural gas & 1,030 (BTU/ft ${ }^{3}$ ) [2] & 0.12 (lb/ft ${ }^{3}$ ) [2] \\
\hline Liquid petroleum gas & 92,096 (BTU/gallon) [2] & 12.8 (lb/gallon) [2] \\
\hline Oil & 138,095 (BTU/gal) [2] & 22.7 (lb/gallon) [2] \\
\hline Ethanol & 84,031 (BTU/gallon) [3] & 12.6 (lb/gallon) [3] \\
\hline Butanol & 108,940 (BTU/gallon) [4] & 16.07 (lb/gallon) [4] \\
\hline Hydrogen & 60,990 (BTU/lb) [5] & 0.00 \\
\hline
\end{tabular}

[1] (Klara 2007); [2] (DOE 2004); [3] (Shapouri , Duffield, and Wang 2002); [4] (Wu et al. 2007); [5] (DOE 2001); [6] (Hong and Slatick 1994) 
Table 3. Common values used in VPMs

\begin{tabular}{|c|c|c|c|}
\hline \multicolumn{2}{|l|}{ Biofuels } & \multicolumn{2}{|c|}{ Electricity } \\
\hline $\begin{array}{c}\text { Ethanol made by wet mill, dry mill } \\
\text { (\%) }\end{array}$ & $55 ; 45$ [1] & $\begin{array}{l}\text { Average distance } \\
\text { for coal transport (mile) }\end{array}$ & 148 [14] \\
\hline $\begin{array}{l}\text { Ethanol; butanol yield } \\
\text { (gal/corn bushel) }\end{array}$ & $\begin{array}{l}2.66[1] \\
2.05[2]\end{array}$ & $\begin{array}{l}\text { Train; Truck efficiency } \\
\text { (ton-miles/gal); (MPG) }\end{array}$ & 423 [15]; 7 [16] \\
\hline $\begin{array}{l}\text { Carbon flux (Pg/year); } \\
\% \text { land w/vegetation }\end{array}$ & $\begin{array}{l}1.05[3] \\
62.3[4]\end{array}$ & $\begin{array}{l}\text { Coal input/kWh output } \\
\text { PSC,IGCC,USC } \\
\text { (Ibcoal/kWh) }\end{array}$ & $\begin{array}{l}0.795[6] \\
0.765[6] \\
0.729[17]\end{array}$ \\
\hline $\begin{array}{l}\text { Fermentation } \mathrm{CO}_{2} \text { emission } \\
\text { ethanol; butanol (lb/gal) }\end{array}$ & $6.32,7.29$ & $\begin{array}{l}\text { Main steam temperature } \\
\text { PSC; USC }\left({ }^{\circ} \mathrm{F}\right)\end{array}$ & $\begin{array}{l}1,050[6] \\
1,100[17]\end{array}$ \\
\hline $\begin{array}{l}\text { DDGS yield ethanol; butanol } \\
\text { (lb/gal) }\end{array}$ & $\begin{array}{l}6.08[5] ; \\
9.03[2]\end{array}$ & $\begin{array}{l}\text { Main steam pressure } \\
\text { PSC;USC (psi) }\end{array}$ & $\begin{array}{l}2,400[6] \\
4,500[17]\end{array}$ \\
\hline $\begin{array}{c}\text { CGF; CGM; corn oil yield ethanol } \\
\text { (lb/gal) }\end{array}$ & $\begin{array}{l}4.49 ; 1.06 \\
0.86[5]\end{array}$ & $\begin{array}{c}\text { Plant efficiency } \\
\text { PSC;IGCC;USC; (\%) }\end{array}$ & $\begin{array}{l}36.8[6] ; 38.2[6] ; \\
\quad 40.1[17]\end{array}$ \\
\hline $\begin{array}{l}\text { DDGS replacement value } \\
\text { (lbcorn/lb) }\end{array}$ & $1.077[5]$ & $\begin{array}{l}\text { Electric car efficiency } \\
\text { (miles/kWh) }\end{array}$ & $2.76[18]$ \\
\hline $\begin{array}{c}\text { CGF; CGM replacement value } \\
\text { (lbcorn/lb) }\end{array}$ & $1.0 ; 1.53[5]$ & $\begin{array}{l}\text { Power line electricity loss } \\
\text { (\%) }\end{array}$ & 8 [19] \\
\hline $\begin{array}{c}\text { Corn oil replacement value } \\
\text { (Ibsoyoil//b) }\end{array}$ & $1.0[5]$ & \multicolumn{2}{|c|}{ Gasoline } \\
\hline $\begin{array}{l}\mathrm{CO}_{2} \text { saved from replacing corn } \\
\text { (lb/lb corn) }\end{array}$ & $\begin{array}{l}0.23 \\
{[1, \text { Table 2] }}\end{array}$ & $\begin{array}{c}\text { Gasoline yield from Oil (kg } \\
\text { gasoline/kg oil) }\end{array}$ & $0.465[20]$ \\
\hline $\begin{array}{c}\mathrm{CO}_{2} \text { saved from replacing soy oil } \\
(\mathrm{lb} / \mathrm{lb} \text { corn })\end{array}$ & $0.7[1$, Table 2] & $\begin{array}{c}\text { Steam production efficiency } \\
(\%)\end{array}$ & 75 \\
\hline $\begin{array}{c}\text { Vehicle efficiency } \\
\text { ethanol; butanol(MPG) }\end{array}$ & $16.06 ; 20.8$ & $\begin{array}{l}\text { Capacity of centennial } \\
\text { pipeline (BPD) }\end{array}$ & $210,000[22]$ \\
\hline $\begin{array}{c}\text { Coal input; kWh output } \\
\text { IGCC/ethanol (lb/gal); (kWh/gal) }\end{array}$ & $\begin{array}{l}14.1[6,7] ; \\
9.86[6,7]\end{array}$ & $\begin{array}{l}\text { Power demand of pumps } \\
\qquad(\mathrm{kW})\end{array}$ & $11,190[22]$ \\
\hline \multicolumn{2}{|c|}{ Gasification/Fuel Synthesis } & $\begin{array}{l}\text { Gasoline transport truck } \\
\text { capacity (gal) }\end{array}$ & $9,246[10]$ \\
\hline $\begin{array}{l}\text { Coal input/ diesel; } \mathrm{H}_{2} \\
\text { (lb/gal); }\left(\mathrm{lb} / \mathrm{lb} \mathrm{H} \mathrm{H}_{2}\right)\end{array}$ & $\begin{array}{l}25.08[8] \\
8.44[9]\end{array}$ & $\begin{array}{l}\text { Gasoline transport truck fuel } \\
\text { efficiency (MPG) }\end{array}$ & $7[16]$ \\
\hline $\begin{array}{c}\text { Excess kWh } \\
\text { diesel: } \mathrm{H}_{2} \text { Plant } \\
\text { (kWh/gal); }(\mathrm{kWh} / \mathrm{lb})\end{array}$ & $\begin{array}{l}2.44[8] \\
1.11[9]\end{array}$ & $\begin{array}{c}\text { Fuel efficiency of gasoline } \\
\text { Vehicle (MPG) }\end{array}$ & 23.9 [12] \\
\hline $\begin{array}{l}\text { kWh Used to compress } \mathrm{H}_{2} \text { to } 7,000 \\
\text { psi (kWh/lb) }\end{array}$ & $1.41[10]$ & \multirow{3}{*}{\multicolumn{2}{|c|}{$\begin{array}{c}\text { MPG= Miles Per Gallon } \\
\text { gal=gallon } \\
\text { BPD=Barrel Per Day } \\
\text { lb=pound } \\
\text { kW= kilowatt } \\
\text { Wh=kilowatt hour of electricity } \\
\text { BTU=British Thermal Units }\end{array}$}} \\
\hline $\begin{array}{c}\text { \% Increase in efficiency diesel to } \\
\text { gasoline; diesel car efficiency } \\
\text { (MPG) }\end{array}$ & $\begin{array}{c}32.5[11] ; 31.7 \\
{[11,12]}\end{array}$ & & \\
\hline Efficiency of hydrogen car (mile/lb) & $25.8[10,13]$ & & \\
\hline
\end{tabular}


[1] (Shapouri et al. 2002); [2] (Ramey 1998); [3] (Griffiths and Jarvis 2005); [4] (Ecological Footprint 2008); [5] (Kim and Dale 2002); [6] (Klara 2007); [7] (Graboski 2002); [8] (Challman 2007); [9] (Chiesa et al. 2005); [10] (Ogden 2004); [11] (Fuel Economy guide 2007); [12] (EPA 2005); [13] (Hordeski 2006);

[14] (Illinois Coal Industry 2007); [15] (AAR 2005); [16] (REI 2006); [17] (Goidich, Song, and Fan 2005);

[18] (DOE and EPA 2009); [19] (Wang 2005); [20] (Wang, Lee, and Molburg 2004); [22] (Business Wire 2001) 


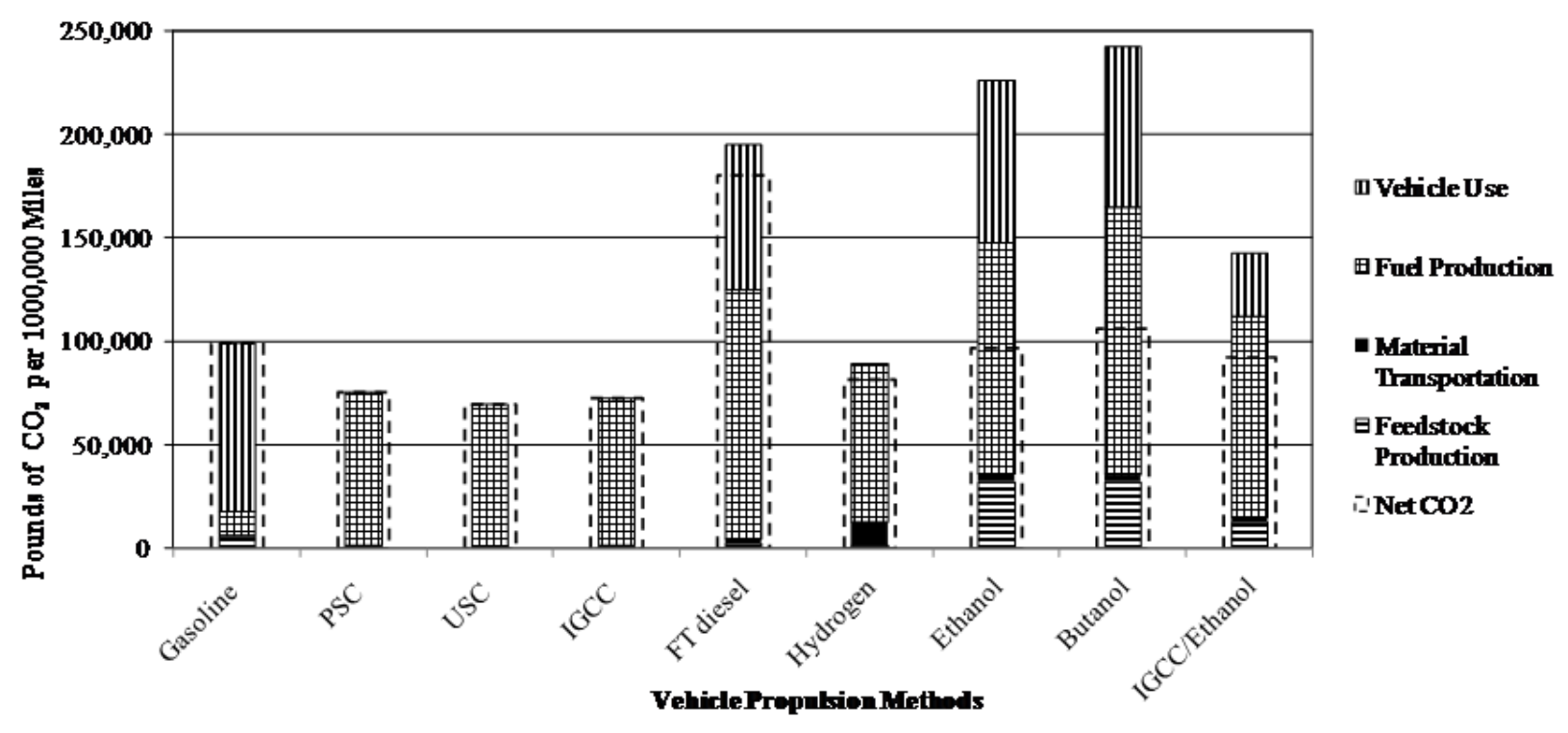

Figure 1. Pounds of $\mathrm{CO}_{2}$ Emitted from the Four General Life Cycle Steps of All Nine Vehicle Propulsion Methods 


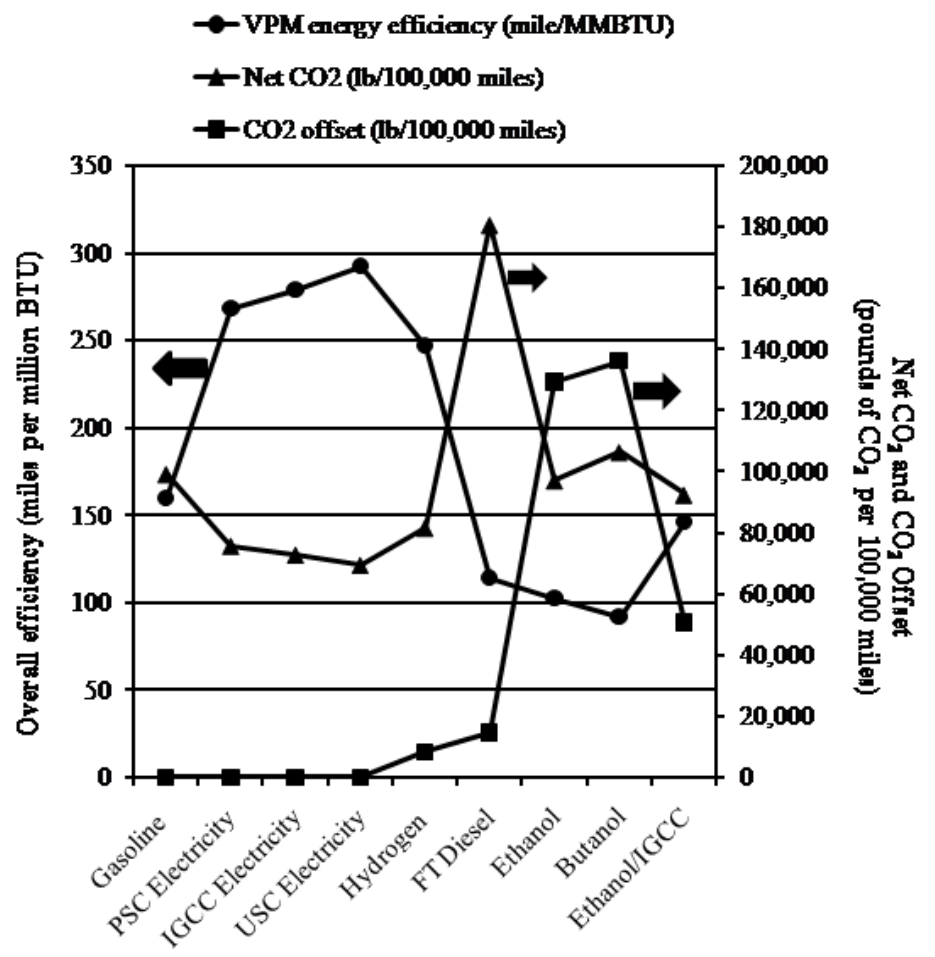

Figure 2: $\mathrm{Net}_{\mathrm{CO}_{2}}$ Emission Plotted with the Energy Efficiency and $\mathrm{CO}_{2}$ Offset of All Nine Vehicle Propulsion Methods 


\section{REFERENCES}

AAR: Policy and Economics Department. 2005. Railroads: Building a Cleaner Environment. Association of American Railroads.

Business Wire. 2001. Centennial Nears Completion on Refined Products Pipeline Conversion in the US. Business Wire.

Challman, D. 2007. Technologies for Producing Transportation Fuels, Chemicals, Synthetic Natural Gas and Electricity from the Gasification of Kentucky Coal. Center for Applied Energy Research, University of Kentucky.

Chiesa, P., Consonni, S., Kreutz, T., and Williams, R. 2005. Co-Production of Hydrogen, Electricity and $\mathrm{CO}_{2}$ from Coal with Commercially Ready Technology. Part B: Economic Analysis. International Journal of Hydrogen Energy 30:769-784.

Daly, Gavin. “\$4.6 Billion Oil Refinery Faces Delay.” Sunday Business Post, 23 March 2008. $<$ http://archives.tcm.ie/businesspost/2008/03/23/story31456.asp> (15 June 2008).

Delucchi, M. 2003. A Lifecycle Emissions Model(LEM): Lifecycle Emissions from Transportation Fuels, Motor Vehicles, Transportation Modes, Electricity Use, Heating and Cooking Fuels, and Materials. Institute of Transportation Studies.

Department of Energy and Environmental Protection Agency. “Advanced Technology and Energy Efficiency and Electric Vehicles.” Department of Energy and Environmental Protection Agency, 2009

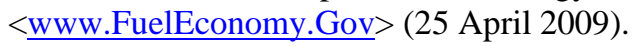

Department of Energy and Environmental Protection Agency. "Fuel Economy Guide.” Department of Energy and Environmental Protection Agency, 6 June 2007. <www.FuelEconomy.Gov> (28 March 2008).

Department of Energy. "Hydrogen Fuel Cell Engines: Module 1 Hydrogen Properties.” Hydrogen Fuel Cells and Infrastructure Program, 2001. < $\underline{w w w 1 . e e r e . e n e r g y . g o v>~(15 ~ M a r c h ~ 2008) . ~}$

Department of Energy. "Voluntary Reporting of Greenhouse Gases.” Energy Information Administration, 2004.

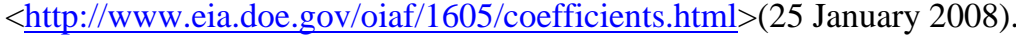

Environmental Protection Agency. "Emission Facts: Greenhouse Gas Emissions from a Typical Passenger Vehicle.” Environmental Protection Agency Paper, No. EPA420-F-05-004 EPA, 2005. $<$ http://www.epa.gov/otaq/climate/420f05004> (15 January 2008).

Evans, D. 2004. Crude Oil and Natural Gas Extraction: 2002 Economic Census. U.S Census Bureau and the Department of Commerce, Paper No. EC02-211-211111.

Global Footprint Network. “The Ecological Footprint.” The Share Guide: The Holistic Health Magazine and Resource Directory. $<$ http://www.shareguide.com/Ecological.html $>$ ( 25 March 2008).

Goidich, S., Song, W., and Fan, Z. 2005. Design Aspects of the Ultra-Supercritical CFB Boiler. International Pittsburgh Coal Conference.

Graboski, M. 2002. Fossil Fuel Use in the Manufacture of Corn Ethanol. National Corn Growers Association.

Griffiths, H. and Jarvis, P. 2005. The Carbon Balance of Forest Bio-dom. Trowbridge, UK: Cromwell Press.

Hordeski, M. 2006. Alternative Fuels, The Future of Hydrogen. Lilburn: Fairmont Press. 
Hong, B., and E. Slatick. “Quarterly Coal Report.” National Department of Energy, Paper No. DOE/EIA-0121, August, 1994. <http://www.eia.doe.gov/cneaf/coal/quarterly/co2_article/co2.html> (20 January 2008)

Kim, S., and Dale B., 2002. Allocation Procedure in Ethanol Production System from Corn Grain. International Journal of Life Cycle analysis1-7.

Klara, J. “Bituminous Coal and Natural Gas to Electricity Final Report.” National Energy Technology Laboratory,

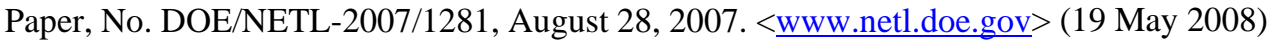

Lavin, Jack. "Illinois Coal Fact Sheet.” Illinois Department of Commerce and Economic Opportunity, December 7, 2006. <www.illinoiscoal.biz> (25 January 2008).

Lavin, J. 2006. The Illinois Coal Industry. Department of Commerce and Economic Opportunity, Report of the Office of Coal Development.

Ogden, J. 2004. Hydrogen Delivery Model for H2A Analysis. Institution of Transportation Studies, Paper No. UCDITS-RR-04-33.

Ramey, D. 1998. Continuous Two Stage, Dual Path Anaerobic Fermentation of Butanol and Other Organic Solvents Using Two Different Strains of Bacteria. US Patent 5,753,474, 19.

REI. REI’s Greenhouse Gas Inventory.” REI, 2006. <www.rei.com/aboutrei/csr/2006/sustain transportation.html> (15 March 2008).

Shapouri, H., Duffield, J., and Graboski, M. 1995. Estimating the Energy Balance of Corn Ethanol. US Department of Agriculture, Report Number 721.

Shapouri, H., Duffield, J., and Wang, M. 2002. The Energy Balance of Corn Ethanol: An Update Economic Agriculture. US Department of Agriculture, Report 813.

Spath, P., Mann, M., and Kerr, D. 1999. Life Cycle Assessment of Coal-fired Power Production. National Renewable Energy Laboratory, Paper No. NREL/TP-570-25119.

Starkey, Darin. 2009. Environmental Analysis of Illinois Coal Entry into the Transportation Market. Master's Thesis, Southern Illinois University Carbondale.

Susta, M., Seon, K., and Melaysia, Z. 2004. Supercritical and Ultra-Supercritical Power Plants-SEA's Vision or Reality?. PowerGen-Asia.

United States Department of Labor. “Consumer Price Index History Table.” Bureau of Labor Statistics, 2009. $<$ http://www.bls.gov/> (15 March 2009).

Wang, M. 2005. Update Energy and Greenhouse Gas Emission Results for Fuel Ethanol. The $15^{\text {th }}$ International Symposium on Alcohol Fuels, 2005.

Wang, M., Lee, H., and Molburg, J. 2004. Allocation of Energy Use in Petroleum Refineries to Petroleum Products. International Journal of Life Cycle Analysis 9(1): 34-44.

Wang, M., Weber, T., and Finizza, A. 2001. Well-to-Wheel Energy Use and Greenhouse Gas Emission of Advanced Fuel/Vehicle Systems. Argonne National Laboratory.

Wu, M., Wang, M., and Huo, H. 2006. Fuel-Cycle Assessment of Selected Bioethanol Production Pathways in the United States. Argonne National Laboratory: Center for Transportation Research, Paper No. ANL/ESD/067. 
Wu, M., Wang, M., Liu, J., and Huo H. 2007. Life-Cycle Assessment of Corn-Based Butanol as a Potential Transportation Fuel. Argonne National Laboratory, Paper No. ANL/ESD/07-10.

\section{Acknowledgement:}

This material is based upon work supported by the Illinois Clean Coal Institute under grant number 07-1/ER10. 